\title{
NOUSUKAUDESTA LAMAAN, MÄÄRÄSTÄ LAATUUN
}

\section{Koulutuksen laadun erilaiset merkitykset}

Laatu on iskusana, jota nykyään käytetään lähes kaikessa koulutusta koskevassa keskustelussa. Koulutuksen laatu ja sen parantaminen ovat ykkössijalla matkalla kohti "Tiedon ja osaamisen Suomea" (VNp 18.6.1993, 5).

Nykyisessä koulutuspolitiikassa laatu ja sen aisapari kansainvälistyminen ovat paitsi tavoitteita itsessään, myös välineitä toistensa saavuttamiseksi. Korkealaatuinen koulutus on tavoite, joka kaikkien on helppo hyväksyä.

Laadun tulo keskeiselle sijalle koulutuspolitiikassa voi selittyä usealla tavalla. Hakemattakin tulee mieleen, onko kyseessä taas uusi "retorinen käänne"

koulutuspolitiikan sanastossa. Kasvu on toki miellyttävämpi puheenaihe kuin supistukset, ja laadun kasvattaminen kuulostaa epäilemättä paremmalta kuin määrän vähentäminen.

Pelkästä retoriikasta tuskin kuitenkaan on kysymys. Uudet muotisanat eivät tule koulutuspolitiikkaan tyhjästä.
Koulutusajat ovat pidentyneet jatkuvasti, jolloin on jouduttu myös kysymään, ovatko uudet tutkinnot aikaisempia laadukkaampia, tai onko yleensäkään olemassa keinoja erilaisten tai eri oppilaitoksessa suoritettujen tutkintojen laadun arviointiin. Resurssikasvun pysähdyttyä peliin on tullut huoli koulutuksen laadun heikkenemisestä. Lisääntyvät kansainväliset kontaktit ovat herättäneet kysymyksen suomalaisen koulutuksen tasosta kansainvälisessä vertailussa. Laadun arviointia on myös enenevästi alettu pitää mahdollisena, vaikka ongelmat arvioinnin käytännön toteutuksessa myönnetäänkin.

\section{Laatu halpaa, määrä kallista?}

Koulutuksen laadun kääntöpuolena on valtiontalouden paha lama. Kun koulutukseen sijoitettavat resurssit joitakin poikkeuksia lukuunottamatta pienenevät - eli kun oppilaitoksia "rationalisoidaan" ja resursseja "vapautetaan" - niin koulutuksen laatu pitäisi samanaikaisesti pystyä säilyttämään, tai sitä pitäisi jopa parantaa.

Tämänhetkisessä rationaalisuuden ja taloudellisen tulosvastuun dogmissamme koulutus on sitä arvokkaampaa, mitä halvemmalla se on tehty. Onko laatu siis halvempaa kuin määrä? "Halvalle laadulle" antaa merkityksen koulutuksen pääasiallinen rahoittaja, valtio. Mutta jos vaikkapa opiskelijaa, professoria, tai vastavalmistuneen työnantajaa pyydetään määrittelemään koulutuksen tai tutkimuksen laatua, niin 
vastauksetkin ovat erilaisia. Kauneus on laadun arvioinnissakin oleellisesti katsojan silmässä.

\section{Eri intressiryhmät ja erillaiset laadut}

Suomen kielen perussanakirjassa (1992) "laadun" yleisin merkitys on asian tai ilmiön "ominaisuudet, luonne, olemus, kvaliteetti." Laadulla tarkoitetaan siis ensisijaisesti asian tai ilmiön ominaispiirteitä, mikä mahdollistaa esimerkiksi vertailun tai yleensä sijoittumisen jollakin asteikolla: "Vertaa bintaa laatuun; Laadultaan ala-arvoista tavaraa".

Erikoismerkityksenä laadulla on saman sanakirjan mukaan "hyvä laatu, laadukkuus", mikä onkin jo absoluuttinen merkitys: "Meillä pyritään laatuun; Laadusta joutuu maksamaan". On sanomattakin selvää, että kyse on korkeasta laadusta: kukapa pyrkisi ehdoin tahdoin huonoon laatuun, tai väittäisi, että huonosta laadusta joutuu maksamaan sen minkä hyvästäkin.

Koulutuspoliittisessa keskustelussa "laatu" esiintyy nimenomaan erikoismerkityksessään: "Laatu ja kansainvälistyminen ovat kehittämislinjan avainsanat" (VNp 18.6.1993, 5). Korkeaan laatuun kurotellaan, sitä tavoitellaan, ja kysytään, miten se on tavoitettavissa. Sinänsä yksinkertainen korkean laadun tavoite saattaa kuitenkin hämärtää keskustelua, kun joudutaan huomaamaan, että laadulla on useampia ulottuvuuksia. "Laatu" on hankala käsite, ja se tuntuu jopa pakenevan määritelmiä. Olisi silti liian helppoa jättää laatu pelkän intuitiivisen merkityksensä varaan.

Laadun määritelmä on olennaisesti sidottu sen kriteerien määrittelijän tarpeisiin ja haluihin. Kun puhumme koulutuksen laadusta, pitää samalla myös kysyä, kenen laadusta on kysymys (Harvey \& Green 1993, 10). Samaan tapaan Barnett (1992, 4-5) pitää laatukeskustelua osana koulutukseen ja sen tarkoitukseen liittyvää valtataistelua. Laadun eri määritelmien taustalla ovat siis perimmältään intressiryhmien käsitykset koulutuksesta ja siltä vaadittavasta laadusta.

\section{Laadun ulottuvuudet}

Harvey ja Green pohtivat perinpohjaisessa artikkelissaan (Harvey \& Green, 1993) laadun aspekteja eri intressiryhmien näkökulmat huomioon ottaen. He esittelevät viisi periaatteellista lähestymistapaa, joihin pohjaten seuraavassa tarkastellaan laadun merkityksiä suomalaisessa koulutuspolitiikassa:

1. poikkeuksellinen laatu (quality as exceptional)

2. tasainen tai virheetön laatu (quality as perfection or consistency)

3. tarkoituksenmukainen laatu (quality as fitness for purpose)

4. laatu tehokkuusvaatimuksena (quality as value for money)

5. laatu muutoksena (quality as transformation)

Poikkeuksellinen laatu kuvastaa perinteistä käsitystä elitistisestä ja absoluuttisesta laadusta: hyvälle laadulle ei ole kriteerejä, sen vain tunnistaa. Kysymys on legitimoiduista mielikuvista ja intuitioista. Poikkeuksellinen laatu kuvastuu usein oppilaitoksen maineessa. Korkeatasoinen oppilaitos vetää puoleensa hyviä hakijoita, jolloin "hyvää laatua" päästään tekemään poikkeuksellisesta oppilasaineksesta. Poikkeukselliseen laatuun sisältyy myös käsitys laadun arvioinnin objektiivisuudesta tai neutraaliudesta.

Poikkeuksellista laatua voi olla myös minimivaatimusten saavuttaminen. Laatu ei tällöin olekaan poissuikeva ja absoluuttinen käsite, vaan jokainen yksilö, yksikkö tai koulutus, joka tavoittaa määrätyt minimivaatimukset, voi kutsua itseään laadukkaaksi. Koulutuksen kehittämissuunnitelmassa oppisopimuskoulutuksen laatu "turvataan", kun taas korkeakoulutuksen laatua "korostetaan" ja "parannetaan" (VNp 18.6.1993, 5-8, 12). Oppisopimuskoulutuksessa toisin sanoen näytetään pyrkivän minimitavoitteiden saavuttamiseen, kun taas korkeakoulutuksessa tavoitellaan maksimilaatua.

Virheetön tai tasainen laatu viittaa kieli- ja mielikuvaan koulutuksesta tuotantoprosessina. Tällöin "tuotteen" pitää olla tarkkaan määritelty. Tässä näkökulmassa korkealaatuinen koulutus tuottaa esimerkiksi tutkintoja ilman "tuotanto- 
häiriöitä" tai "virheellisiä tuotteita", kuten opintojen pitkittymistä, opiskeluaikaista työssäkäyntiä, tai tarkkaan rajattuun ammattiin sopimattomia tutkintoja. Aiheellisesti voi kysyä, voidaanko koulutustuotteet ylipäätään määritellä niin tarkkaan, että tällaista tuotantokontrollia voitaisiin edes ajatella.

Tarkoituksenmukainen laatu on sukua tasalaatuisuudelle sikäli, että lähtökohtana ovat koulutukselle asetetut vaatimukset. Tarkoituksenmukainen laatu tarkoittaa tuotteen - tutkinnon, tutkimuksen jne. - kykyä joko täyttää "asiakkaan" vaatimukset tai "tuottajan" omat tavoitteet. Lähtökohtana voi siis toisaalta olla esimerkiksi opiskelijan koulutukselle tai työnantajan oppilaitoksesta valmistuvalle asettamat vaatimukset, tai toisaalta oppilaitoksen (ääneenlausuttu) tehtävä tai tarkoitus. Tarkoituksenmukainen laatu on tällöin asetettujen tavoitteiden saavuttamista (vrt. Vaherva 1992, 140).

Kun poikkeuksellinen laatu ei voi koskaan olla liian hyvää, niin tarkoituksenmukaisella laadulla on paitsi ala-, myös ylärajansa. Liian korkea koulutus saattaa esimerkiksi työnantajien kannalta olla epätarkoituksenmukaista, siis ei-laadukasta. Puhutaan ylikoulutuksesta. Tarkoituksenmukainen laatu lieneekin lähinnä työnantajien intressissä (ks. STK-TKL 1991, 5).

Tehokkuuden laatunäkemyksen taustalla on usko koulutuksen markkinaohjautuvuuteen, ja keskeistä tässä näkökulmassa on taloudellinen tulosvastuu koulutuksen rahoittajalle. Suomi ei ole ainoa länsimaa, jossa taloudellisen laman seurauksena on tultu siihen johtopäätökseen, että koulutukseen uhrattavat varat ovat ainakin toistaiseksi katossaan. Valtiovallan lamaliturgia "halvemmalla parempaa" kuvastaa oivasti näkemystä siitä, että laadun keskeinen kriteeri on taloudellinen tehokkuus.

Laatu muutoksena sisältää oletuksen siitä, että esimerkiksi opiskelijassa tapahtuu muutos opiskelun seurauksena. Isossa-Britanniassa tätä muutosta on konkretisoitu arvonlisän käsitteen avulla (ks. esim. Williams \& Loder 1990; Pollitt 1990). Ajatellaan, että laadukas oppilaitos on sellainen, joka tuottaa eniten "lisäarvoa" eli jossa opiskelijat oppivat tai kehittyvät eniten. Kärjistetysti sellainen oppilaitos, joka kouluttaa huonoista oppilaista hyviä tutkinnon suorittajia, on parempi kuin huippuaineksesta huippuammattilaisia valmistava.

\section{Esimerkki korkeakoulutuksesta: työllistyminen koulutuksen laadun kriteerinä?}

Koulutussosiologian tutkimuskeskuksessa käynnissä olevassa korkeakoulujen toiminnan arviointia koskevassa tutkimuksessa on haastateltu viime vuosien systemaattisissa arvioinneissa keskeisesti mukana olleita henkilöitä (ks. Saarinen 1993). Haastateltavien vastauksista löytyi odotetusti erilaisia "laatuja". Ajan hengen mukaisesti laadun arviointia pidettiin tärkeänä ja mahdollisenakin, vaikka osa haastateltavista alkoi perua käsitystään arvioinnin mahdollisuudesta, kun sen toteutustavat tulivat puheeksi. Laatua näytettiin pitävän melko itsestään selvänä käsitteenä. Korkeakouluista ja etenkin niissä tehtävästä tutkimuksesta puhuttaessa "laatua" käytettiin usein merkityksessä "poikkeuksellinen" laatu: korkea laatu, jonka olemassaolon huomaa, ja joka erottaa yliopiston tai laitoksen muista.

Koulutuksen laadusta ja sen arvioinnista kysyttäessä monet haastateltavista sen sijaan esittivät keskeiseksi arviointikriteeriksi tutkinnon suorittaneen sijoittumista työelämässä, tai yleensäkin työllistymistä. Korkeakoulujen toiminnan tuloksellisuutta on tähän mennessä arvioitu lähinnä suoritettujen tutkintojen ja muiden opintosuoritusten perusteella. Nyt myös valtiovalta on ottamassa työelämään sijoittumisen yhdeksi tuloksellisuuden kriteeriksi (VNp 18.6.1993, 17).

Tuntuu paradoksaaliselta, että työttömyyden ollessa parinkymmenen prosentin luokkaa työelämään sijoittumista halutaan pitää koulutuksen laadun tai edes tuloksellisuuden kriteerinä, ikään kuin koulutuksen absoluuttinen laatu takaisi koulutetun absoluuttisen työllistymisen. Työelämään sijoittumistakin voi sitäpaitsi tarkastella useammalta taholta. Onko koulutuksen laadun tai tuloksellisuuden kannalta eroa sillä, saako tutkinnon suorittaja valmistuttuaan ylipäänsä mitään työtä, vai sijoittuuko hän mahdollisesti koulutustaan vastaavaan työhön? 


\section{Taulukko 1.}

\section{Korkeakoulututkinnon suorittaneiden työttömyys} 30.6.1993 ja valmistuneiden määrä vuonna 1992.

\begin{tabular}{lcccc}
\hline & $\begin{array}{l}\text { Työttömät ilman } \\
\text { lomautettuja }\end{array}$ & $\begin{array}{l}\text { Työttömistä } \\
\text { vastavalmistuneet }\end{array}$ & $\begin{array}{l}\text { Avoimet } \\
\text { työpaikat }\end{array}$ & $\begin{array}{l}\text { Valmistu- } \\
\text { neet }\end{array}$ \\
\hline Alempi kk-tutkinto & 6235 & 892 & 68 & \\
Perustutkinto & 9782 & 1321 & 87 & $9459^{1)}$ \\
Jatkotutkinto & 428 & 24 & 10 & 1197 \\
Yhteensä & 16445 & 2237 & 165 & 10656 \\
\hline
\end{tabular}

Mitä työllistyminen laadun kriteerinä kertoisi korkeakoulutuksesta? Vastavalmistuneet joutuvat akateemisesti koulutettujen joukossakin työttömiksi muita todennäköisemmin. Alemman tai ylemmän perustutkinnon suorittaneita työttömiä oli työministeriön tilastojen mukaan kesäkuun lopussa 1993 yhteensä 16117 eli lähes saman verran, kuin uusia korkeakouluopiskelijoita vuosittain. Akateemisista työttömistä noin $14 \%$ oli vastavalmistuneita. (Taulukko 1.) Jatkotutkinnon suorittaneita oli samaan aikaan työttömänä runsas 400 , kun edellisenä vuonna oli valmistunut 1197 uutta lisensiaattia ja tohtoria.

Erityisen haavoittuvaisia ovat tällä hetkellä humanistinen (ei opettajankoulutus), tekninen ja luonnontieteellinen sekä yhteiskuntatieteen ja kaupan ala. Näissä vastavalmistuneiden työttömyys oli jo vuoden 1992 loppupuolella 20\% luokkaa, kun akateeminen työttömyys oli kaikkiaan 4\% (Myrskylä, 1993).

Koulutuksella työnhakija voi parantaa suhteellista asemaansa työvoimajonossa (Silvennoinen 1993, 11). Tässä katsannossa siis laadukas koulutus auttaa hakijaa ohittamaan vähemmän korkeatasoisella koulutuksella - tai tutkintotodistuksella - varustetut kilpailijansa. Kyse ei ole "absoluuttisesta" tai poikkeuksellisesta laadusta, jonka kaikki voisivat tavoittaa (ja jolloin kaikki työllistyisivät), vaan laatu on suhteessa siihen, miten määrätyn koulutuksen saaneet työllistyvät muihin samantyyppisen koulutuksen saaneisiin verrattuna.
Koulutuksen laatua parantamalla ei luoda uusia työpaikkoja. Mutta entä jos koulutetun työllistymisellä tai sijoittumisella tarkoitetaankin hänen kykyään työllistää itse itsensä? Parikin korkeakoulutusta edustavaa haastateltavaa esitti ajatuksen spontaanisti. Olisiko työttömyys merkki koulutuksen huonosta laadusta, jos akateemisesti koulutettu työnhakija ei pysty myymään itseään työmarkkinoilla? Vai olisiko sittenkin kyseessä työnhakijan henkilökohtainen epäonnistuminen?

\section{Lopuksi}

Laadun ja sen arvioinnin tärkeydestä tunnutaan olevan kovasti yksimielisiä. Laatu on kaunis ja arvokas tavoite, johon kaikkien on helppo yhtyä. Tarkemmin katsottuna laadun merkitys on kuitenkin moniselitteinen ja erilaisiin intresseihin sidottu. Ideaalinen käsitys kaikille samaan muottiin valetusta laadusta vain houkuttelee koulutuspoliittisen keskustelun kävijät kuvittelemaan, että kun käytetty sanasto on sama, niin myös puheenaihe on yhteinen.

Erkki Kaukonen pohdiskeli alkuvuodesta 1993 ilmestyneessä Korkeakoulutieto-lehdessä otsikolla "Tieteen moninaisuus ja arvioinnin ongelmat" toisaalta tieteen ja tiedeyhteisön, toisaalta tutkimuksen ja tutkimusyhteisön merkityksiä. Hän päätyi säästämään "tiedeyhteisön" juhlavaan käyttöön ja suositteli, että arkikieles- 
sä puhuttaisiin vain tutkimusyhteisöstä. Samalla analogialla "laadun" voisi säästää ylevämmälle merkitykselleen, juhlapuheisiin ja visioihin, ja keskittyä arkielämässä katsannosta riippuen "laadun" eri aspekteihin, kuten esimerkiksi tutkintojen suorittamisen tehokkuuteen, tutkimuksen kykyyn herättää mielenkiintoa ja uusia ajatuksia, tai oppilaitosten kykyyn käyttää niille annetut resurssit järkevästi. Ymmärrys laadun merkityksestä lähtisi siitä ymmärryksestä, että eri intressiryhmät kohdistavat koulutukseen erilaisia odotuksia ja vaatimuksia. Tällöin myös koulutuksen laadulla tarkoitetaan eri asioita. Erilaisilla laaduilla on muitakin ulottuvuuksia kuin hyvyys tai huonous.

\section{LÄHTEET}

Barnett, R. 1992. The Idea of Quality: Voicing the Educational. Higher Education Quarterly 46 (1), 3-19.

Harvey, L. \& Green, D. 1993. Defining Quality. Assessment \& Evaluation in Higher Education 18 (1), 9-34.

Kaukonen, E. 1993. Tieteen moninaisuus ja arvioinnin ongelmat. Korkeakoulutieto 20 (1), 16-23.

Kota 1992. Helsinki: Opetusministeriö.

STK-TKL 1991. Koulutuksen laatu. Helsinki: Teollisuuden koulutusvaliokunta, sarja A/12.

Myrskylä, P. 1993. Keistä tuli työttömiä? Selvitys työttömien työnhakijoiden taustoista. Työpoliittinen tutkimus 43. Helsinki: Työministeriö.

Pollitt, C. 1990. Measuring University Performance: Never Mind the Quality, Never Mind the Width? Higher Education Quarterly 44 (1), 60-81.

Saarinen, T. 1993. The Universities and the Ministry of Education in Finland: Where Does Assessment Fit in? Paper presented at the 15th EAIR Forum, August 15-18 1993, Turku, Finland.

Silvennoinen, H. 1993. Työvoimakoulutuksesta työmarkkinoille: suhdanteet ja sijoittuminen. Työpoliittinen aikakauskirja 2/1993, 3-13.

Suomen kielen perussanakirja 1992. Helsinki: Valtion painatuskeskus.

TM 1993:6. Työministeriön tilastoja 1993 kesäkuu. Helsinki: Työministeriö.

Vaherva, T. 1992. Työelämän aikuiskoulutusta arvioimassa. Aikuiskasvatus 12 (2), 136-140.

VNp 18.6.1993. Koulutuksen ja korkeakouluissa harjoitettavan tutkimuksen kehittämissuunnitelma 19911996. Valtioneuvoston päätös 18.6.1993. Helsinki: Opetusministeriö.
Williams, G. \& Loder, C. 1990. The Importance of Quality and Quality Assurance. Teoksessa C. Loder (toim.) Quality Assurance and Accountability in Higher Education. London: Kogan Page, 1-12. 